\section{Prejudiced reporting?}

SIR - Because any doubt thrown on the integrity of a scientist has serious consequences, such allegations should be dealt with only with extreme caution, and the rule underlying any democratic society, that any person should be held innocent until proved guilty, should be scrupulously followed. In my opinion, the spirit of the articles published in Nature on the investigation involving the research of $\mathrm{Dr}$ Karl Illmensee does not fully conform to that rule.

Like many others, I was shocked to hear that doubts had been cast on the credibility of a well-known scientist. The information published in Nature (2 June, p.363) and Science (3 June, p.1023) on the subject was that suspicions were being harboured against Dr K. Illmensee and that committees had been appointed in Geneva and Bar Harbor to investigate the case. However, although it was not explicitly stated, the extensive coverage of the case in Nature in a news item and the reference to it in an editorial entitled "Is science really a pack of lies?' left the impression that the accusations against Illmensee were founded. This constitutes, unwittingly, the passing of a judgement against the scientist and the manipulation of public opinion.

Moreover, I was surprised to witness the relative ease with which many scientists accepted the truth of the charges (or even rumours before these publications) against a colleague, without knowing the relevant facts. This, in my opinion, is a disturbing symptom and may reflect low standards of the mutual trust which is so important for the progress of scientific research.

A correct attitude towards scientific honesty should make it all the more difficult to accept that a well-known scientist has resorted to fraud. The instinctive reaction to such a charge (as long as proof had not been found) should have been disbelief. In all fairness, we should give our colleagues the elementary right to a fair and respectable investigation, free of unsubstantiated and biased public opinion.

DAvid YAFFE

\section{Department of Cell Biology, Weizmann Institute of Science, Rehovot 76100, Israel}

DR YAFFE is right to insist on the principle that a person must be supposed innocent unless proved guilty but wrong to suggest that Nature's reporting tends otherwise. Both the articles to which he refers stem from an announcement by the University of Geneva that an internal investigation had been completed, and that steps were being taken (at the end of May) to appoint an external commission of inquiry. After more than two months, the membership of that committee was announced; it met for the first time at the end of August. Meanwhile, Nature has been glad to report that an investigation at the Jackson
Laboratory in Bar Harbor of Dr Illmensee's work there has exonerated him and his US colleagues from blame (see Nature 16 June, p.563).

For a university to report that an investigation has been found necessary is, fortunately, rare, and necessarily a matter of public interest. To have failed to report such a development and to describe the background to it would more properly have been held to be "the manipulation of public opinion". But Nature knows nothing substantial that it has not published, has not prejudged the issue, has not sought advance information from the members of the investigating commission, agrees with $\mathrm{Dr}$ Yaffe that the scientific community should also await the outcome of that investigation and hopes, in everybody's interests that it will not be much longer delayed. Justice should be swift as well as impartial.

Editor, Nature

\section{Sizewell safety}

SIR - Your leading article exhorting the government to "end the Sizewell agony" (Nature 4 August, p.382) suggested that the terms of the inquiry should be restricted to local planning issues, while the question of whether reactors of particular types are in some acceptable sense "safe", is a matter for central government. Yet is it not now widely accepted that a community should have a very major say in what risks it is to bear? The protracted inquiry is providing an essential forum for that say.

Certainly the inquiry is costly, but a wrong decision could be more so. An inquiry restricted to local planning issues would have neither the breadth nor the depth to examine the fundamental criteria upon which thorough decision making should be based.

9d Stanhope Road,

London N6 SNE, UK

\section{Steps against arms}

SIR - M.C. Goodall (Nature 4 August, p.390) is of course free to make his own deductions about what the scientific establishment is so dismally doing to influence the arms race. The impression given by his letter is that he is dismally unaware of what is happening in this field. The Pugwash movement has just held a conference on "Avoiding Nuclear and Other Wars and Reversing the Arms Race"'.

The Pontifical Academy organized recently a number of meetings that led to a Declaration of the Prevention of Nuclear War adopted in the Vatican by representatives of 36 National Academies of Science and of international scientific organizations.
The special number of Ambio (Vol. XI Nos 2-3, 1982), 'Nuclear War: The Aftermath" was also the work of scientists under the sponsorship of the Royal Swedish Academy of Sciences. There have been other activities by national groups of scientists, with another at the end of October in Washington DC on "The World After Nuclear War"'.

The International Council of Scientific Unions (ICSU) at its 19th General Assembly in 1982 resolved to make an assessment of the biological, medical and physical effects of the large-scale use of nuclear weapons - this is just beginning and ICSU's Scientific Committee on Problems of the Environment is already undertaking a study of the environmental consequences of nuclear war, the first stage of which will concentrate on the atmospheric aspects.

Perhaps the scientists are dilatory and dismally doing little - but do other professional groups have better track records?

MIKE BAKER

(Executive Secretary)

International Council of

Scientific Unions,

51, Bd de Montmorency, 75016 Paris, France

\section{Novel DNA structure}

SIR - We look forward to Nature's Symposium: Molecular Biology Now \& Tomorrow. If the advertisement that has appeared in many issues of this journal is any indication, the conference should provide real excitement. We find it especially amazing that after 30 years DNA continues to yield basic structural secrets; we refer specifically to the structure of DNA depicted in the advertisement for this symposium. Who would have thought that one strand could become left-handed while the other strand remained right-handed?

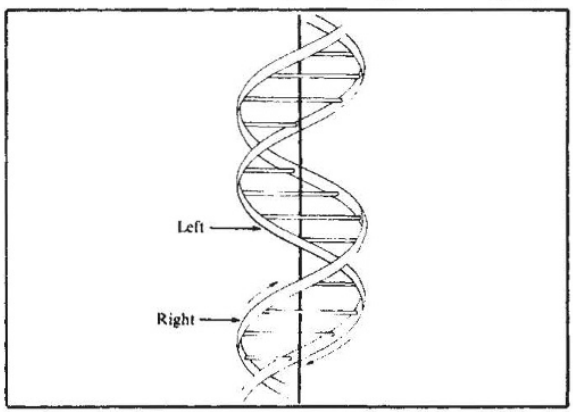

Since this structure appears as yet unnamed, may we suggest it be called E-DNA in honour of the great illusionary artist M.C. Escher. Leave it to Nature to usher in Escher DNA?

Department of Biochemistry, Baylor College of Medicine, Houston, Texas 77030, USA

Department of Biochemistry Peter B. Berget

and Molecular Biology, University of Texas Medical School, Houston, Texas 77030, USA 